\title{
Efektivitas Model Pembelajaran Think Pair Share Berbantuan Media VBSC untuk Meningkatkan Kemampuan Penalaran Siswa
}

\author{
Hela Dhera Antafani* dan Kartika Yuni Purwanti \\ Universitas Ngudi Waluyo \\ Email Korespondensi: heladhera17@gmail.com
}

\begin{abstract}
This study aims to determine the effectiveness of the Think Pair Share (TPS) learning model assisted by sound-based core video (VBSC) media to improve reasoning abilities in the volume material. This type of research is an experimental design with a pretest-posttest control group design. Data were collected using observation, interviews, and reasoning ability questionnaires. Data were analyzed by normality test, homogeneity test, independent sample t test, paired sample test, t test and simple linear regression test. The results of the research show: (1) There is an effect of using the TPS learning model assisted by VBSC media on the reasoning ability in the volume material of building space, this is evidenced by the significance level of $0.000<0.005$ with std.Error Mean experimental class more than std. The Errorr Mean for the control class is 0.641 $>0.625$ so Ha can be accepted (2) There is a difference in the use of the the TPS learning model assisted by VBSC media on the reasoning ability in the volume material of building space, this is evidenced by the significance $<0.05$, which is $0.02<0.05$, and $0.000<0.05$ and (3) The TPS learning model assisted by VBSC media is effective in improving reasoning ability in the material of volume building, this is evidenced by a significance level of $0.000<0.005$ with std The Error Mean of the experimental class is more than std. The Error Mean of the control class is $0.641>$ 0.625 .
\end{abstract}

Keyword: Think Pair Share, Sound-Based Core Video Media, Reasoning Ability, Volume of Building Space.

\section{Abstrak}

Penelitian ini bertujuan untuk mengetahui keefektifan model pembelajaran Think Pair Share (TPS) berbantuan media video sound based core (VBSC) untuk meningkatkan kemampuan penalaran dalam materi volume bangun ruang. Jenis penelitian ini adalah eksperimen dengan Desain pretest- posttest control group design. Data dikumpulkan dengan menggunakan observasi, wawancara, angket kemampuan penalaran. Data dianalisis dengan uji normalitas, uji homogenitas, uji independent sample t test, uji paired sample test, uji t dan uji regresi linear sederhana. Hasil penelitian menunjukkan: (1) Terdapat pengaruh penggunaan model pembelajaran TPS berbantuan media (VBSC) terhadap kemampuan penalaran dalam materi volume bangun ruang, hal ini dibuktikan dengan taraf signifikansi 0,000 0,005 dengan std.Error Mean kelas eksperimen lebih dari std.Error Mean kelas kontrol yaitu 0,641 >0,625 
sehingga Ha dapat diterima (2) Terdapat perbedaan penggunaan model pembelajaran TPS berbantuan media (VBSC) terhadap kemampuan penalaran dalam materi volume bangun ruang, hal ini dibuktikan dengan signifikansi $<0,05$, yaitu 0,02 <0,05, dan 0,000<0,05 dan (3) Model pembelajaran TPS berbantuan media (VBSC) efektif dalam meningkatkan kemampuan penalaran dalam materi volume bangun ruang, hal ini dibuktikan dengan taraf signifikansi 0,000 < 0,005 dengan std.Error Mean kelas eksperimen lebih dari std.Error Mean kelas kontrol yaitu 0,641>0,625.

Kata kunci: Pembelajaran Think Pair Share, Media VBSC, Kemampuan Penalaran, Volume Bangun Ruang

\section{A. Pendahuluan}

Proses pembelajaran merupakan hubungan timbal balik antara guru dan siswa yang terjadi dengan baik untuk mencapai tujuan pembelajaran yang hendak dicapai. Matematika merupakan ilmu tentang bilangan dan berhubungan erat dengan hitung-menghitung (Perwitasari, dkk, 2014). Pembelajaran matematika penting untuk diajarkan pada setiap jenjang kelas di sekolah agar mencetak siswa yang handal dalam menghadapi perubahan zaman melalui penguasaan matematika (Amir, 2015).

Matematika memiliki fungsi yang sangat penting dalam kehidupan seharihari, banyak persoalan yang harus dipecahkan dalam kemampuan matematika, seperti menghitung, mengukur dan menalar dalam kehidupan sehari-hari. Misalnya menghitung volume bangun ruang dan mengukur panjang sisi bangun ruang dengan menggunakan penalaran untuk memahaminya. Proses pembelajaran matematika siswa harus menghitung angka- angka yang berhubungan dengan rumus dan banyak menghafalkan rumus-rumus, sehingga siswa kesulitan jika tanpa adanya kemampuan penalaran yang baik dan benar.

Peran penting matematika diakui Cockroft (Shadiq, 2014) yaitu akan sangat sulit atau tidaklah mungkin bagi seseorang untuk hidup dibagian bumi ini pada abad ke-20 ini tanpa sedikitpun memanfaatkan matematika. Membangun sistem pembelajaran aktif, inovatif dan kreatif dapat mencapai penguasaan materi matematika dalam mengembangkan kemampuan penalaran.

Menurut Russeffendi, matematika lebih menekankan kegiatan dalam dunia rasio (penalaran), bukan menekankan dari hasil eksperimen atau hasil observasi. Matematika terbentuk karena pikiran-pikiran manusia yang berhubungan dengan 
idea, proses, dan penalaran. Sistem pembelajaran yang baik akan meningkatkan kemampuan matematis pada diri siswa. Sumartini (dalam Usniati, 2011) menyebutkan salah satu kecenderungan yang menyebabkan siswa gagal menguasai dengan baik pokok-pokok bahasan dalam matematika yaitu siswa kurang memahami dan menggunakan nalar yang baik dalam menyelesaikan soal yang diberikan. Padahal kemampuan menalar menjadi salah satu capaian dalam pembelajaran matematika di sekolah yaitu melatih cara berpikir dan bernalar dalam menarik kesimpulan, mengembangkan kemampuan memecahkan masalah, serta mengembangkan kemampuan menyampaikan informasi atau mengkomunikasikan ide-ide melalui lisan, tulisan, gambar, grafik, peta, diagram, dan sebagainya (Depdiknas, 2006).

Menyelesaikan soal cerita dan memahami persoalan dengan memecahkan masalah menggunakan penalaran yang baik dapat menarik kesimpulan dan menemukan jawaban dengan baik (Suriasumantri, 1999). Hal ini menjelaskan penalaran merupakan suatu proses berpikir dalam menarik suatu kesimpulan yang berupa pengetahuan. Kemampuan penalaran siswa berdasarkan hasil observasi dan wawancara yang dilakukan di SDN Madyocondro Magelang kelas VA dengan jumlah 19 siswa dan KKM 70 menunjukkan kemampuan penalaran tinggi berjumlah 5 siswa dengan $26,31 \%$ dan 14 siswa dengan kemampuan penalaran rendah 73,68\%. Kelas VB dengan jumlah siswa 24 dengan KKM 70 yang menunjukkan kemampuan penalaran tinggi berjumlah 7 siswa dengan $36,84 \%$ dan 12 siswa dengan kemampuan penalaran rendah 63,15\%.

Tes kemampuan penalaran yang pernah diberikan kepada siswa sebagai berikut:

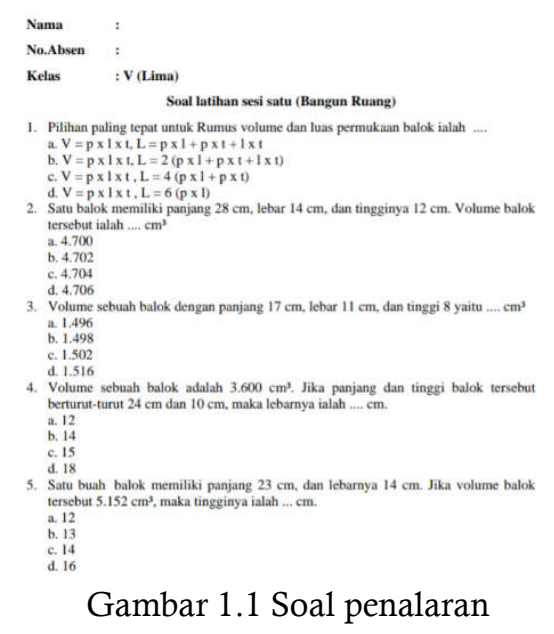


Berdasarkan soal yang pernah diberikan, soal nomor satu termasuk indikator NCTM (2000) mengenal aspek mendasar matematika dengan konsep dasar rumus volume bangun ruang. Soal nomor dua dan tiga termasuk dalam indikator membuat dan menyelidiki dugaan matematika dengan mencari sebuah hasil menggunakan penyelesaian. Nomor empat dan lima termasuk dalam indikator memilih dan menggunakan berbagai tipe penalaran untuk mencari suatu jawaban. Hasil yang diperoleh siswa diketahui bahwa kemampuan siswa dalam menyelesaikan soal masih kurang.

Berdasarkan wawancara yang pernah dilakukan di sekolah ditemukan data bahwa pada SDN Madyocondro Kelas VA sebesar 73,68\% dan kelas VB sebesar $68,13 \%$ kemampuan penalaran masih rendah. Hasil wawancara peneliti melalui wawancara langsung wali kelas menyatakan bahwa rendahnya penalaran siswa pada mata pelajaran matematika, yang seringkali masih susah dalam menerapkan konsep dasar dalam matematika sehingga kemampuan dalam menalar masih rendah pada materi bangun ruang. Keterbatasan waktu dan sistem pembelajaran online mengakibatkan belajar siswa kurang optimal dengan berbagai kendala yang dialami. Seperti tidak adanya pendampingan belajar siswa secara langsung, baik dari orangtua atau yang lainnya.

Masalah ini timbul karena proses pembelajaran yang terjadi secara online dan konvensional sehingga pembelajaran hanya terjadi satu arah saja, komunikasi dan interaksi antara guru dan siswa berkurang dan mengakibatkan pembelajaran kurang bermakna. Selain itu masalah kemampuan penalaran siswa masih rendah dengan sulitnya siswa dalam membuat analogi, dugaan atau bukti dan membuat kesimpulan dalam memahami soal matematika. Untuk mengatasi permasalahan tersebut, maka guru perlu menggunakan model dan media pembelajaran yang mampu meningkatkan kemampuan penalaran model dan media yang sesuai dengan karakteristik siswa melalui pembelajaran yang bermakna dengan pengalaman baru nya terhadap pembelajaran online.

Kemampuan penalaran siswa akan meningkat apabila diimbangi dengan penggunaan model pembelajaran. Menurut Simanjutak (dalam Nurulwati, 2000) mengemukakan maksud dari model pembelajaran adalah kerangka konseptual yang melukiskan prosedur yang sistematis dalam mengorganisasikan pengalaman 
belajar untuk mencapai tujuan belajar tertentu, dan berfungsi untuk sebagai pedoman bagi para perancang pembelajaran dan para pengajar dalam merencanakan aktivitas belajar mengajar.

Salah satu model pembelajaran yang dapat digunakan untuk meningkatkan kemampuan penalaran siswa adalah Think Pair Share (TPS). Menurut (Trianto, 2010) model pembelajaran kooperatif tipe think pair share adalah model pembelajaran kooperatif yang efektif dalam pola pembelajaran diskusi. Prosedur yang digunakan dalam think pair share dapat membuat siswa lebih banyak waktu berpikir, merespon, dan saling membantu. Penelitian yang dilakukan Slavin (Hery Saputra, 2019) menunjukkan bahwa pembelajaran kooperatif menjadikan siswa untuk belajar aktif untuk saling menunjukkan diri atau berperan diantara temanteman sebayanya. Selain itu pembelajaran dengan model kooperatif dapat membangun semangat siswa untuk saling membantu dalam memecahkan masalah yang dihadapi dalam belajar.

Model pembelajaran TPS merupakan model pembelajaran kooperatif yang sederhana dan baik digunakan dalam pembelajaran bagi seorang guru pemula dengan pendekatan kooperatif. Model ini memperkenalkan gagasan tentang waktu "tunggu atau berpikir" (wait or think time) pada elemen interaksi pembelajaran kooperatif yang saat ini menjadi salah satu faktor ampuh dalam meningkatkan respon siswa terhadap pertanyaan (Jumanta, 2011). TPS memiliki prosedur yang secara eksplisit memberi siswa waktu untuk berfikir, menjawab, saling membantu satu sama lain (Shoimin, 2014). Dengan demikian, siswa diharapkan mampu bekerja sama, saling membutuhkan, dan saling bergantung pada kelompok kecil secara kooperatif.

Model pembelajaran TPS akan lebih bermakna jika ditambahkan penggunaan media. Salah satu media yang dapat digunakan adalah video based core yang mana sebuah PPT yang dirangkai menjadi sebuah video pembelajaran berbasis suara, tidak hanya musik akan tetapi diberikan penjelasan mengenai isi dari video tersebut. Menurut Putra (2019), dengan menggunakan media alat peraga (model bangun ruang) dapat memberikan konsep abstrak matematika dalam bentuk konkrit sehingga materi yang disampaikan dapat dipahami dan dimengerti. 
Media pembelajaran adalah alat bantu yang digunakan guru untuk mendukung proses pembelajaran supaya tujuan pembelajaran dapat tercapai dengan baik. Media pembelajaran akan meningkatkan keinginan belajar siswa dan mengajak siswa untuk belajar dengan melihat langsung benda atau media yang digunakan yang akan mempermudah dalam proses pembelajaran, karena siswa dapat berfikir konkrit jika media nyata dapat digunakan dengan baik.

Keberadaan media menjadi penting adanya, karena pendekatan, metode atau strategi apapun yang digunakan dalam pembelajaran tidak akan memberikan manfaat dan makna apapun terhadap peningkatan mutu pembelajaran selama dalam penggunaan media pembelajaran tidak optimal (Haryoko, 2010; Sunaengsih, 2015; Nurseto, 2011). Penelitian tentang model TPS untuk meningkatkan kemampuan penalaran sudah banyak diteliti. Peneliti mencoba menambahkan media video sound based core (VSBC) untuk memotivasi siswa dalam pembelajaran sehingga kemampuan penalaran siswa akan meningkat.

Model yang digunakan salah satunya model pembelajaran TPS dengan melibatkan kelompok kecil yang akan memberikan pengalaman belajar siswa dan mendapatkan informasi berulang-ulang, sehingga siswa akan lebih memahami materi. Pembelajaran akan efektif jika berbantuan media pembelajaran. Untuk mendukung pembelajaran secara online, media yang digunakan adalah video sound based core (VSBC) yang merupakan video presentasi linear dengan slide-slide yang berisikan materi yang ditambahkan animasi, audio dan durasi waktu yang ditentukan sehingga menjadi sebuah video pembelajaran yang berisikan inti materi. Penelitian ini dilakukan secara online sehingga dalam menerapkan model TPS yang berupa small group discussion dan media VSBC dengan menggunakan aplikasi belajar berupa zoom, akan memberikan pengalaman baru dalam pembelajaran online di era pandemic. Dalam penelitian ini membutuhkan suatu populasi dan diambil sampel sesuai dengan karakteristik sebagai penelitian dengan permasalah tersebut.

Berdasarkan uraian latar belakang di atas, maka peneliti tertarik untuk melakukan penelitian dengan judul keefektifan model pembelajaran TPS berbantuan media VSBC untuk meningkatkan kemampuan penalaran dalam materi volume bangun ruang. Untuk mendapatkan hasil yang optimal dan tepat 
maka penelitian ini akan dilaksanakan melalui penelitian kuantitatif eksperimen dengan kelas kontrol sebagai pembanding.

\section{B. Metode Penelitian}

Penelitian ini merupakan penelitian kuantitatif, dimana hasil penelitian diukur dalam bentuk angka lalu diolah menggunakan teknik analisis statistik. Metode Quasi Experimental yang merupakan metode penelitian untuk mengatasi kesulitan dalam menentukan kelompok kontrol dalam penelitian (Sugiyono, 2018) digunakan dalam penelitian ini. Dengan demikian, metode ini bertujuan untuk mendapatkan kelompok kontrol dalam sebuah penelitian yang pada kenyataanya sulit ditemukan.

Penelitian ini menggunakan desain penelitian Nonequivalent Group Design. Kelompok pertama yang dikenai perlakuan berupa model pembelajaran TPS berbantuan media VBSC yaitu kelompok eksperimen, kelompok kedua dikenai perlakuan yang berbeda adalah kelompok kontrol sebagai pembanding (Sugiyono, 2018). Di bawah ini akan dijelaskan desain Nonequivalent Group.

Tabel 3.1 Desain Penelitian

Tabel 3.1 Desain Penelitian
\begin{tabular}{|c|c|c|c|}
\hline Kelompok & Awal & Perlakuan & Tes Akhir \\
\hline Eksperimen & O & X & O \\
\hline Kontrol & O & Y & O \\
\hline
\end{tabular}

Keterangan :

$\mathrm{X} \quad=$ Perlakuan dengan model pembelajaran TPS berbantuan media video sound based core

$\mathrm{Y} \quad=$ Pembelajaran menggunakan model TPS.

$\mathrm{O}=$ Instrumen hasil belajar aspek kognitif (tes tertulis), sikap ilmiah (lembar observasi/angket) kelas eksperimen dibandingkan dengan kelas kontrol.

\section{Hasil dan Pembahasan}

Pembahasan hasil penelitian ini merupakan pengkajian dari hasil penelitian yang mempunyai tujuan untuk mencapai makna hasil penelitian yang telah dilakukan. Pembahasan ini dilakukan dengan mendiskusikan temuan sebagai hasil penelitian dengan kajian teori atau latar belakang yang telah dibahas pada bab sebelumnya.

1) Perbedaan Penggunaan Model Pembelajaran TPS Berbantuan Media VBSC terhadap Kemampuan Penalaran Siswa Mata Pelajaran Matematika Volume Bangun Ruang. 
Berdasarkan hasil penelitian diperoleh data bahwa model pembelajaran TPS berbantuan media VBSC lebih efektif digunakan dalam pembelajaran. Nilai rata-rata siswa yang diberi perlakuan lebih tinggi daripada nilai rata-rata siswa yang tidak diberi perlakuan. Model pembelajaran TPS berbantuan media VBSC efektif digunakan untuk membuat siswa menjadi lebih tinggi. Persentase rata-rata nilai kelas eksperimen lebih tinggi daripada kelas kontrol.

Perbedaan ini disebabkan karena kelompok eksperimen diberi perlakuan dengan media sehingga siswa menjadi lebih mudah dalam memahami pembelajaran. Oleh karena itu, guru sebaiknya menggunakan model dan media pembelajaran yang inovatif agar siswa tidak bosan serta selalu mendapat nilai baik dalam setiap pembelajaran.

Kesimpulan ini diperkuat oleh penelitian Putri,dkk (2019) yang menyatakan bahwa klasifikasi kemampuan penalaran matematis ditinjau dari kemampuan pemecahan masalah siswa dengan data klasifikasi penalaran matematika didapatkan persentase sebesar 70\% pada aspek memahami pengertian dalam kategori tinggi. Selain itu penelitian Sudiantini dan Shinta (2018) menyatakan bahwa pengaruh penggunaan media pembelajaran terhadap kemampuan penalaran matematika Fhitung $=22,883>$ Ftabel $=4,20$ artinya terdapat pengaruh yang signifikan. Selain itu penelitian Nataliasari (2015) menyatakan bahwa dengan hasil penelitian terdapat peningkatan perbedaan penalaran kemampuan dan pemecahan masalah matematis dengan model kooperatif lebih baik dengan nilai hitung 3,082 dan nilai table 1,667 taraf signifikan 0,05 $\mathrm{t}$ hitung $>\mathrm{t}$ table.

Model pembelajaran TPS berbantuan media VSBC efektif untuk membuat nilai siswa menjadi lebih tinggi sehingga model dan media ini sangat cocok digunakan dalam pembelajaran. Dari wawancara yang sudah dilakukan, bahwa terdapat perbedaan pemberian model dan media pembelajaran dengan yang tidak diberi. Hal ini karena dengan penggunaan model dan media maka siswa akan lebih antusias dalam menerima pembelajaran. Untuk pembelajaran yang tidak menggunakan model dan media pembelajaran maka mereka akan cenderung malas-malasan saat pembelajaran berlangsung, baik itu saat proses pembelajaran berlangsung ataupun saat siswa mengerjakan pekerjaan rumah. 


\section{2) Pengaruh Penggunaan Model Pembelajaran TPS Berbantuan Media VSBC} terhadap Kemampuan Penalaran Siswa Mata Pelajaran Matematika Volume

\section{Bangun Ruang}

Berdasarkan hasil penelitian diperoleh data bahwa model pembelajaran TPS berbantuan media VSBC berpengaruh terhadap kemampuan penalaran siswa. Hal ini dapat diketahui dari hasil yaitu variabel X (model pembelajaran TPS berbantuan media VSBC) berpengaruh pada Y (kemampuan penalaran). Penggunaan model dan media pembelajaran ini membuat siswa lebih mampu mengembangkan kemampuan penalaran. Persentase rata-rata kemampuan penalaran siswa pada kelompok eksperimen lebih tinggi daripada kelompok kontrol.

Hal ini mungkin karena disebabkan oleh kegiatan-kegiatan siswa pada kelompok eksperimen untuk menjadi siswa aktif dalam berpikir dan mampu melihat benda dengan nyata melalui video pembelajaran. Pada kelompok kontrol kegiatan pembelajaran sedikit aktif dikarenakan belum ada media yang menarik bagi siswa sehingga siswa sedikit kesulitan dalam merealisasikan bangun ruang. Untuk mengatasinya maka guru menggunakan model pembelajaran serta media pembelajaran di kelas dengan berbagai aktivitas belajar yang bervariasi agar pengalaman belajar siswa menjadi lebih bermakna sehingga semua potensi dalam diri siswa terutama kemampuan berpikir akan berkembang. Model pembelajaran TPS berbantuan media VSBC ini mampu membuat kemampuan penalaran siswa menjadi lebih optimal.

Kemampuan penalaran yang optimal ini bisa dilihat dari keaktifan dengan bertanya dan menyatakan pendapat dalam kegiatan pembelajaran. Rata-rata skor pada kelompok eksperimen yaitu 82 dan rata-rata skor pada kelompok kontrol yaitu 78. Dalam pembelajaran yang menggunakan model pembelajaran TPS berbantuan media VSBC mampu membuat siswa mengutarakan pendapat dan menjawab pertanyaan yang menggunakan penalaran dengan baik.

Kesimpulan ini diperkuat oleh penelitian Maryani (2017) yang menyatakan bahwa uji ANOVA didapat sebesar 31,896. Apabila nilai tersebut dibandingkan dengan nilai sebesar 3,15, maka dapat disimpulkan bahwa dengan demikian hipotesis $\mathrm{H} 0$ ditolak dan $\mathrm{H} 1$ diterima, yang berarti bahwa 
terdapat pengaruh model pembelajaran TPS berbantuan software Geogebra lebih baik dari model pembelajaran konvensional. Selain itu diperkuat oleh penelitian Ditasoa (2013) menyatakan bahwa penerapan pendekatan differentiated instruction dalam kemampuan pemecahan masalah dan penalaran matematis siswa SMA dengan hasil menunjukkan perbedaan peningkatan kemampuan penalaran matematis siswa.

Hasil ini sejalan dengan pendapat Slavin et.el. (1998) bahwa terdapat pengaruh positif pembelajaran kooperatif yang dilaksanakan secara berkelompok terhadap kemampuan pemecahan masalah yang juga mampu meningkatkan penalaran. Selain itu diperkuat oleh penelitian Octaviyunas dan Ekayanti (2018) menyatakan Model pembelajaran GQGA tidak lebih efektif daripada model pembelajaran TPS dalam meningkatkan kemampuan penalaran siswa dengan rata-rata hasil post test $63,13>75,50$. Dapat disimpulkan bahwa model pembelajaran mampu meningkatkan kemampuan penalaran matematis siswa.

Model pembelajaran TPS berbantuan media VSBC cocok diterapkan dalam pembelajaran matematika SD pada materi bangun ruang. Tujuan dari model pembelajaran TPS berbantuan media VSBC ini yaitu memberikan pembelajaran bermakna bagi siswa dengan menggali kemampuan penalaran siswa dalam pembelajaran sehingga mereka mampu meningkatkan kemampuan berpikir logis dalam memahami materi. Dari wawancara kepada guru kelas, penggunaan model dan media pembelajaran mempunyai pengaruh untuk kemampuan penalaran siswa. Siswa lebih dapat memahami dengan bantuan media yang diberikan karena dapat melihat secara langsung realisasi materinya sehingga kemampuan berpikir siswa dapat berkembang.

3) Keefektifan Model Pembelajaran TPS Berbantuan Media VSBC dalam Meningkatkan Kemampuan Penalaran Siswa Mata Pelajaran Matematika Volume Bangun Ruang

Berdasarkan hasil penelitian diperoleh data bahwa model pembelajaran Think Pair Share berbantuan media video sound based core mampu meningkatkan kemampuan penalaran siswa. Pada Tabel 4.3 diketahui bahwa hasil pada kelompok eksperimen yang diberi perlakuan lebih tinggi daripada 
kelompok kontrol yang tidak diberi perlakuan. Nilai tes pada kelompok eksperimen mengalami kenaikan yang signifikan dari rata-rata nilai awal 66 menjadi 82. Kenaikan pada kelompok eksperimen ini dimungkinkan karena pemahaman materi yang baik oleh siswa, sehingga banyak siswa yang mampu mengerjakan soal dengan benar. Jadi dapat disimpulkan bahwa model pembelajaran TPS berbantuan media VSBC mampu meningkatkan kemampuan penalaran siswa sehingga hasil belajar meningkat.

Kesimpulan ini diperkuat oleh penelitian Zulkarnain (2016) yang menyatakan bahwa peningkatan kemampuan penalaran matematis siswa yang belajar dengan model pembelajaran kooperatif tipe TPS lebih baik dari peningkatan kemampuan penalaran matematis siswa yang belajar dengan pembelajaran konvensional, dengan rata-rata kelas eksperimen lebih tinggi daripada kelas kontrol yaitu 0,8286 dengan kualifikasi tinggi dan 0,5562 dengan kualifikasi sedang. Selain itu diperkuat oleh penelitian Adio (2015) menyatakan bahwa kemampuan penalaran matematis siswa menggunakan model pembelajaran TPS lebih baik, dengan meningkatnya rata-rata indicator menunjukkan apresiasi terhadap soal penalaran matematis yaitu 3,2 > 3,36> 3,1. Selain itu diperkuat oleh penelitian Nataliasari (2014) menyatakan bahwa peningkatan kemampuan penalaran dan pemecahan masalah matematis menggunakan model pembelajaran TPS lebih baik daripada konvensional dengan perbedaan rata-rata 0,04 sehingga Ha diterima.

Model pembelajaran TPS berbantuan media VBSC efektif dalam proses pembelajaran. Dengan model pembelajaran TPS berbantuan media VBSC bisa meningkatkan kemampuan penalaran siswa sedangkan yang diberi perlakuan tanpa menggunakan media hanya pengetahuan dari teman belajarnya saja yang meningkat, tidak dengan realisasi logika dalam bangun ruang karena hanya mengangan-angan suatu benda. Sehingga bisa disimpulkan bahwa penggunaan model pembelajaran TPS berbantuan media VBSC lebih efektif daripada kelas yang diberi perlakuan tanpa menggunakan media VBSC.

Dari hasil wawancara yang dilakukan, guru menyebutkan bahwa penggunaan model dan media pembelajaran sangat efektif diberikan di kelas. Model dan media ini bisa digunakan untuk menyingkat waktu dan memberikan 
pengalaman baru bagi siswa. Pengalaman baru itu tentunya akan membuat kemauan siswa dalam belajar juga akan meningkat.

\section{Kesimpulan}

Berdasarkan hasil penelitian diperoleh data bahwa model pembelajaran Think Pair Share berbantuan media video sound based core mampu meningkatkan kemampuan penalaran siswa dengan taraf signifikansi $0,000<0,005$ dengan std.Error Mean kelas eksperimen lebih dari std.Error Mean kelas kontrol yaitu 0,641 > 0,625 sehingga Ha dapat diterima. Dengan demikian diketahui bahwa hasil pada kelompok eksperimen yang diberi perlakuan lebih tinggi daripada kelompok kontrol yang tidak diberi perlakuan. Maka penggunaan model pembelajaran TPS berbantuan media VBSC mampu meningkatkan penalaran siswa.

$* * * * * * * * *$

\section{Daftar Pustaka}

Arikunto. (2010). Prosedur Penelitian Suatu Pendekatan Praktik. Jakarta : Rineka Cipta

Alis, Rantau. (2020). Peningkatan aktivitas dan hasil belajar siswa pada mata pelajaran matematika melalui model pembelajaran koperatif tipe Think Pair Share. Jurnal Junjungan Pendidikan: Intelektual dan Edukatif 1.1 62-80.

Berasa, Darmawanty. (2020). Penerapan Model Pembelajaran Think Pair Share untuk Meningkatkan Hasil Belajar IPA Siswa Sekolah Dasar. Suara Guru 4.(3) 823-832.

Depdiknas. (2006). Kurikulum Tingkat Satuan Pendidikan (KTSP). Jakarta: Depdiknas.

Fadlah, F. (2014). Meningkatkan Motivasi Belajar Siswa pada Pembelajaran IPA dengan Menggunakan Model Pembelajaran Think Pair Share di kelas V SD. Elementary School Journal PGSD FIP UNIMED, 2(1).

Haruna, N. H., \& Darwis, M. (2020). Pengaruh Model Pembelajaran Kooperatif Tipe Make a Match Terhadap Hasil Belajar Matematika. Publikasi Pendidikan, 10(3), 223-231.

Isjoni. (2010). CooperatifLearning, Efektifitas Pembelajaran Kelompok. Bandung: Alfabeta.

Joyce, B., Weil, M., and Calhoun, E. (2009). Models of Theaching: Model-model Pengajaran. Yogyakarta: Pustaka Belajar 
Kurnia Putri, C. (2016). Peningkatan Keaktifan dan Prestasi Belajar IPA Melalui Penerapan Model Pembelajaran Kooperatif Tipe STAD pada Siswa Kelas IV SD Negeri Glagahan Tahun Ajaran 2015/2016. Yogyakarta: Fakultas Keguruan dan Ilmu Pendidikan Universitas Dharma Yogyakarta.

Lestari, A. P.(2013). Peningkatan Motivasi Belajar Siswa Dengan Penerapan Model Pembelajaran Kooperatif Tipe TPS (Think Pair Share) Dalam Pembelajaran IPS Kelas IV Sekolah Dasar. Jurnal Penelitian Pendidikan Guru Sekolah Dasar. 1(2), 19.

Lestari Harahap, Ria, Yulia Pratiwi Siregar, and Roslian Lubis. (2020) Efektivitas Penggunaan Modelpembelajaran Think Pair Share (Tps) Terhadap Kemampuan Pemecahan Masalah Matematis Siswa Di Ponpes Al-Mukhtariyyah Sungai Dua. Jurnal MathEdu (Mathematic Education Journal) 3.1 (87-96).

Mahsup, M., Islahudin, I., \& Anwar, Y. S. (2018). Pelatihan Penggunaan Media Pembelajaran Untuk Meningkatkan Pemahaman Dalam Menentukan Volume Bangun Ruang Bagi Siswa Sekolah Dasar. Selaparang Jurnal Pengabdian Masyarakat Berkemajuan, 2(1), 27-30.

Maut, Wa Ode Arini. (2020). Meningkatkan Hasil Belajar Siswa pada Materi SifatSifat Bangun Datar dan Bangun Ruang melalui Model Pembelajaran Kooperatif Tipe Think-Pair-Share (TPS) di Kelas V SD Negeri 8 TONGKUNO. Gema Pendidikan 27.1 (42-49).

Nasution, K. Pengemasan Materi Pembelajaran Tari Wira Pertiwi Berbasis Powerpoint Stand Alone Untuk Sekolah Menengah Atas. Gesture: Jurnal Seni Tari, 9(2), 185-194.

Nurastuti, (2007). Teknik Pengumpulan Data. Jakarta: Bumi Aksara.

Noerantika, Rera, and Habibatul Latifah. (2019). Efektivitas Penerapan Model Kooperatif Tipe Think Pair Share Berbantu Alat Peraga terhadap Motivasi dan Hasil Belajar pada Materi Aljabar Kelas VII SMPN 1 Boyolangu. JKPM (Jurnal Kajian Pendidikan Matematika 4.1 (29-34).

Noor, Nuralim, and Imam Munandar. (2019). Pengaruh Model Pembelajaran Kooperatif (Tipe TAI dan TPS) dan Aktivitas Belajar terhadap Hasil Belajar Matematika. Jurnal Ilmu Pendidikan (JIP) STKIP Kusuma Negara 11.1 (65-75).

Riduwan. (2014). Skala Pengukuran Variabel-variabel Penelitian. Jakarta: Bumi Aksara.

Slavin, E. Robert. (2008). Cooperative Learning Teori Riset dan Praktik. Bandung: Nusa Media.

Subarinah,Sri. (2006). Inovasi Pembelajaran Matematika SD. Jakarta: Departemen Pendidikan nasional.

Sugiyono. (2018). Metode Penelitian Kuantitatif, Kualitatif dan R\&D. Bandung: Alfabeta.

Sumarsya, Cici Veronika, and Syafri Ahmad. (2020). Think Pair Share sebagai Model untuk Meningkatkan Motivasi Peserta Didik dalam Pembelajaran. Jurnal Pendidikan Tambusai 4.2 1374-1388.

Susanto, A. (2013). Teori Belajar dan Pembelajaran di Sekolah Dasar. Jakarta: Kencana Prenada Media Group. 
Trianto. (2009). Mendisain Model Pembelajaran Inovatif Progresif. Jakarta: Kencana Prenada Group.

Utaminingsih, Retno, and Dyan Asih Pratiwi. (2019). Pengaruh Model Pembelajaran Kooperatif Tipe Think Pair Share Terhadap Prestasi Belajar Ipa Ditinjau Dari Keaktifan Siswa. Taman Cendekia: Jurnal Pendidikan Ke-SD-an 3.1 290-296.

Wahyuni, R. (2018). Pengaruh Penggunaan Model Pembelajaran Kooperatif Tipe Student Team Achievement Divisions (STAD) Terhadap Hasil Belajar Matematika Siswa Kelas $V$ Sd Negeri 5 Metro Pusat. Lampung: Fakultas Keguruan dan Ilmu Pendidikan Universita Lampung.

Wahyuni, S., Rahmadhani, E., \& Mandasari, L. (2020). Pelatihan Pembuatan Media Pembelajaran Interaktif dengan Menggunakan Powerpoint. Jurnal Abdidas, 1(6), 597-602. 